\title{
Paraparesis secondary to erratic migration of Dioctophyma renale in a dog
}

\author{
Paraparesia secundária a migração errática de Dioctophyma renale em cão
}

\author{
Fernando Swiech Bach ${ }^{\mathrm{I}}$ Paulo Roberto Klaumann ${ }^{\mathrm{II}}$ Fabiano Montiani-Ferreira ${ }^{\mathrm{III}}$
}

ABSTRACT

A 4 years old mongrel stray bitch, weighing $16 \mathrm{~kg}$ was submitted to physical examination to demonstrated inability of locomotion with the pelvic limbs. Extradural spinal cord compression was observed in myelotomography of the thoracolumbar segment. The patient was submitted to exploratory hemilaminectomy of $T_{13}-L_{1}$ and $L_{1}-L_{2}$, in an attempt to decompress the medullar segments. During the surgery was observed one adult parasite, identified as Dioctophyma renale, located in the extradural space and causing spinal cord compression. The patient was submitted to postoperative physical therapy, presenting clinical improvement 15 days after surgery, remaining on prone position and able to move the pelvic limbs, but not yet able to walk unassisted. It started walking naturally 60 days after the surgery. With the present clinical report, the erratic migration of the parasite Dioctophyma renale should be added to the list of differential diagnoses for patients with paraparesis and extramedullary lesion pattern, especially in endemic areas.

Key words: dioctophymathosis, paraplegia, neurology, canine.

RESUMO

Uma cadela errante, com $16 \mathrm{~kg}$ de peso e aproximadamente 4 anos de idade foi submetida ao exame fisico por demonstrar déficit de locomoção dos membros pélvicos. A mielotomografia revelou compressão extradural da medula espinhal, no segmento toracolombar. A paciente foi submetida a uma hemilaminectomia exploratória $T_{13}-L_{1}$ e $L_{1}-L_{2}$, na tentativa de descompressão do segmento mencionado. Durante a cirurgia, foi observado um parasita nematódeo adulto, identificado como Dioctophyma renale, localizado no espaço extradural e causando compressão medular. Instituída fisioterapia pós-operatória, a cadela apresentou melhora clínica após 15 dias do procedimento cirúrgico, mantendo-se em estação com capacidade para movimentar os membros pélvicos e passou a caminhar 60 dias após a cirurgia. Dessa forma, pode-se considerar a migração errática de Dioctophyma renale como diagnóstico diferencial para pacientes com paraparesia e padrão de lesão extramedular, especialmente em regiões nas quais a parasitose seja endêmica.

Palavras-chave: dioctofimatose, paraplegia, neurologia, canino.

Paraparesis is a medical term used to designate bilateral partial motor dysfunction, which more frequently occurs in the pelvic limb. It is a common clinical sign in dogs and frequently associated with thoracolumbar spinal cord disease. To embrace the majority of differential diagnosis for the patient with paraparesis, it is suggested to list diseases according to categories such as infectious diseases, vascular diseases; traumatic diseases; congenital disorders and degenerative diseases (PLATT \& OLBY, 2004; DEWEY, 2008). The present note reports the erratic location of Dioctophyma renale (D. renale) within the spinal cord canal of a bitch.

A 4 years old mongrel stray bitch, weighing $16 \mathrm{~kg}$ was treated at the Clinivet Vet Hospital in Curitiba - PR. The female dog was found in the streets two days before the ambulatory care. During general physical examination it was observed that the patient had normo colored mucosa, normothermia and absence of abdominal

\footnotetext{
'Departamento de Neurologia, Clinivet Hospital Veterinário, Curitiba, PR, Brasil.

IIDepartamento de Anestesiologia, Clinivet Hospital Veterinário, Rua Holanda, 894, 82540040, Curitiba, PR, Brasil. E-mail: paulo_rk@terra.com.br. Corresponding author.

IIIDepartamento de Medicina Veterinária, Universidade Federal do Paraná, Curitiba, PR, Brasil.
} 
pain. Pelvis and thoracolumbar spine radiographs were performed, as well as blood count, ALT and creatinine serum measurement. Then abdominal ultrasonography and urinalysis were performed. All aforementioned tests showed results within normal limits and no parasite eggs were observed in urinalysis. Neurological evaluation was performed, which demonstrated inability of locomotion with the pelvic limbs (paraparesis). No pain on palpation of the epaxial muscles of the spine was observed.

Myelotomography of thoracolumbar segment was then performed with injection of iohexol contrast 30\% (Omnipaque ${ }^{\circledR}$ GE Helth Care, Shanghai, China) in the cisterna magna at a dose of $0.4 \mathrm{~mL} / \mathrm{kg}$ showing obstruction of contrast line from $\mathrm{T}_{13}-\mathrm{L}_{1}$ characterizing extradural spinal cord compression, without signs of bone lysis. Liquor analysis showed normal results with no increase in the number of inflammatory cells.

Upon completion of myelotomography, patient was submitted to an exploratory left lateral hemilaminectomy of $\mathrm{T}_{13}-\mathrm{L}_{1}$ and $\mathrm{L}_{1}-\mathrm{L}_{2}$, since there was still no definitive diagnosis, and also to a therapeutic approach in an attempt to decompress the mentioned segments. During the surgery the presence of an adult parasite, located in the extradural space and causing spinal cord compression was observed. During the surgical procedure it was possible to remove the helminth completely (Figure 1). The worm was $20 \mathrm{~cm}$ long and $5 \mathrm{~mm}$ wide; presenting bright red color appearance and taper at both the anterior and posterior ends. It was observed a bursa, which is used to facilitate mating. The parasite was identified as an adult male $\boldsymbol{D}$. renale (PEDRASSANI, 2009).

Patient remained hospitalized for 5 days after surgery in order to provide adequate analgesic and antibiotic protocols, and submitted to postoperative physical therapy, presenting clinical improvement 15 days after surgery, remaining on prone position and being able to move the pelvic limbs. The bitch started walking naturally 60 days after the surgery.

Image diagnoses can be performed by myelography, myelotomography or magnetic resonance imaging and classified according to their location as extradural, intradural extramedullary intrathecal or intramedullary. In the present case the lesion was classified at the yelotomography as extradural lesion (SHARP \& WHEELER, 2005).

Due to evidence of dorsal spinal cord compression in the diagnostic imaging exams, it was partially excluded herniated intervertebral disc, since the compression by disc herniation commonly affects the ventrolateral area of the spinal canal. Radiographic signs were not suggestive of bone neoplasia, especially due to the absence of vertebral lysis. Finally, after myelotomography, the main differential diagnoses were compression by hemorrhage secondary to trauma or to the presence of soft tissue neoplasia. During the surgical procedure, it was found the presence of a parasite $D$. renale, which appeared still alive in the extradural space.

The helminth belongs to class Nematoda and superfamily Dioctophymatoidea with a complex lifecycle, parasitizing kidneys of dogs and men with massive destruction of the corticomedullary layers. Sometimes it could be found in other organs such as abdominal cavity, or in the mesenteric lymph nodes, chest cavity, stomach and even between the liver lobes. (KANO et al., 2003; COLPO et al., 2007; ALVES et al., 2007; LEMOS et al., 2010; ROSA et al., 2011; COTTAR et al., 2012;).

It has worldwide distribution and is often described parasitizing domestic and wild carnivores (LORENZ, 2011; MONTEIRO et al., 2002). Helminth preferentially occurs in stray dogs, with slight selective eating habits (KOMMERS et al., 1999; LEITE et al., 2005).

Based upon the parasite's life cycle, authors suggested that during its migration to the right kidney, the helminth accidentally entered into an intervertebral foramen leading into the spinal canal, what would explain its erratic location.

Clinical signs observed in the patient were only the ones related to neurological condition, though the superficial sensitivity was preserved, it was also observed a bilateral proprioception deficit, an increased muscle tone, increased patellar reflex and an intact anal-tail reflex. The neurological signs determined the neurolocation of the injury to the thoracolumbar segment $\left(\mathrm{T}_{3}-\mathrm{L}_{3}\right)$. Due to the absence of systemic signs related to parasitological infection and normal results of laboratory tests performed in this case, the parasitosis by $\boldsymbol{D}$. renale was not a plausible hypothesis among the differential diagnosis of paraparesis. Parasite eggs search was negative in urinalysis and there were no changes in the renal ultrasound because of its erratic location, characterizing the present case as a unique infection. Liquor sample analysis was negative for the presence of parasite eggs, as well.

With the present case report, the erratic migration of the parasite $\boldsymbol{D}$. renale should be added to the list of differential diagnoses for patients with paraparesis and extramedullary lesion pattern, especially in endemic areas. 


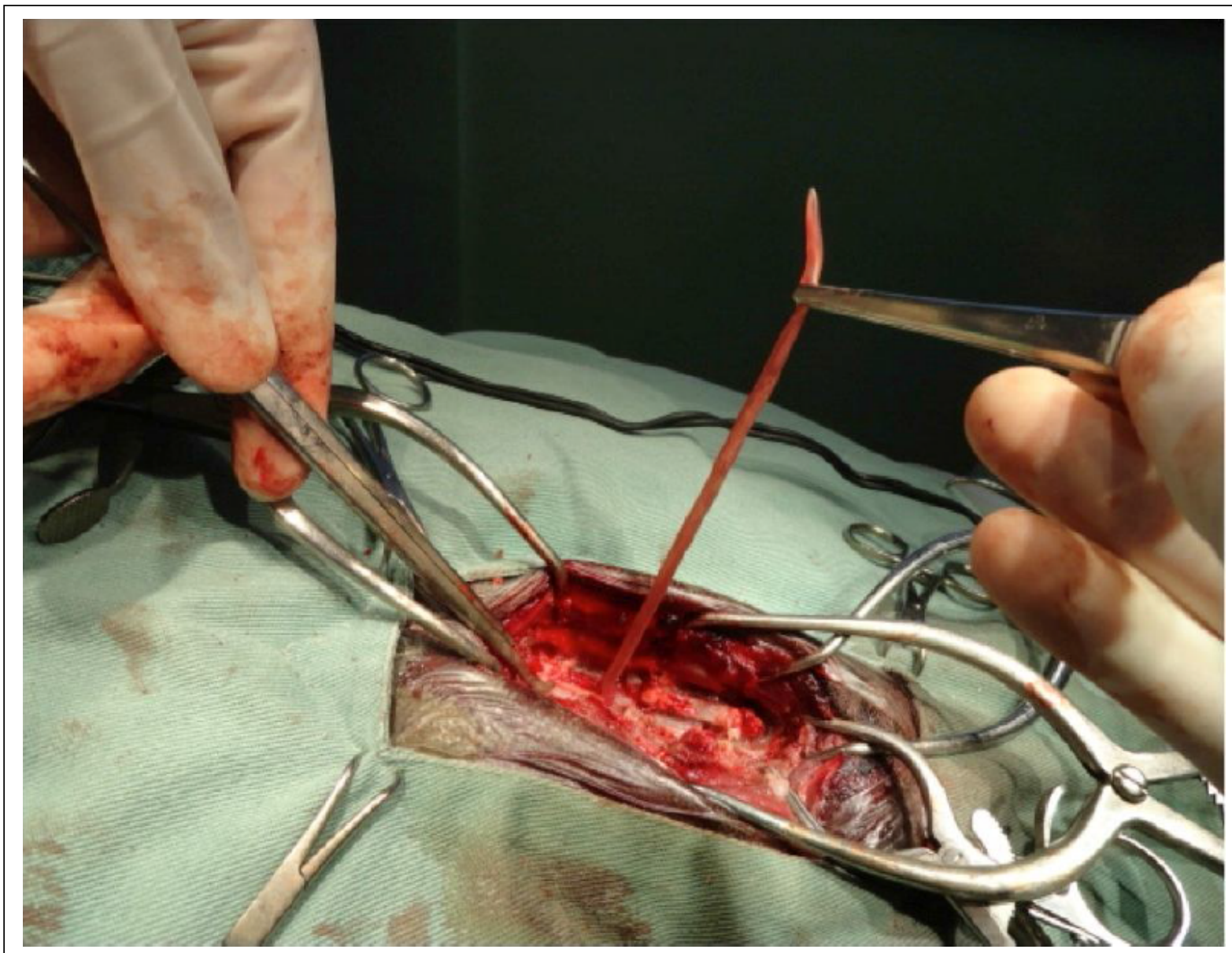

Figure 1 - Surgical removal of parasite from extradural space with Cushing forceps during hemilaminectomy in a dog.

\section{BIOETHICS \\ AND COMMITTEE APPROVAL}

We authors of the article entitled "Paraparesis secondary to erratic migration of Dioctophyma renale in a dog" declared, for all due purposes, that the project that gave rise to the present data has not been submitted for evaluation to the Ethics Committee of the Universidade Federal do Paraná (UFPR), but we are aware of the content of the Brazilian Resolutions of the Conselho Nacional de Controle de Experimentação Animal (CONCEA) <http://www.mct.gov.br/index.php/content/ view/310553.html $>$. Thus, the authors assume full responsibility for the presented data and are available for possible questions, if they are required by the competent authorities.

\section{REFERENCES}

ALVES, G.C. et. al. Dioctophyma renale: o parasita gigante do rim. Revista Científica Eletrônica de Medicina Veterinária, Faculdade de Medicina Veterinária e Zootecina Garça, SP, Ano IV, n.08, 2007. Available from: $<\mathrm{http}: / /$ faef.revista.inf.br/imagens_arquivos/ arquivos_destaque/fPXZwNY3BuYYQ8A_2013-5-24-11-38-31. pdf $>$. Accessed: Nov. 10, 2014.

COLPO, C.B. et. al. Ocorrência de Dioctophyma renale em cães no município de Uruguaiana - RS. Revista da FZVA,
Uruguaiana, v.14, n.2, p.175-180, 2007. Available from: $<$ http://revistaseletronicas.pucrs.br/ojs/index.php/fzva/article/ viewFile/2509/1968>. Accessed: Nov. 10, 2014.

COTTAR, B.H. et. al. Achados ultrassonográficos de cães parasitados por Dioctophyma renale - Estudo retrospectivo. Veterinária e Zootecnia, Botucatu, Brasil, v.19, n.1, Supl. 1 p811, 2012. Available from: <http://www.fmvz.unesp.br/rvz/index. php/rvz/article/download/216/177>. Accessed: Nov. 10, 2014.

DEWEY, C.W. A practical guide to canine and feline neurology 2.ed. Iowa: Willey-Blackwell, 2008. 720pp.

KANO, F.S. et. al. Ocorrência da dioctofimose em dois cães no município de Guarapuava - PR. Semina: Ciências Agrárias, Londrina, v.24, n.1, p.177-180, 2003. Available from: $<\mathrm{http}: / / \mathrm{www}$. uel.br/revistas/uel/index.php/semagrarias/article/view/2147/1843>. Accessed: Nov. 10, 2014. doi: 10.5433/1679-0359.2003v24n1p177.

KOMMERS, G.D. et. al. Diocthophymosis in dogs: 16 cases. Ciência Rural, Santa Maria, v.29, n.3, p.517-522, 1999. Available from: <http://www.scielo.br/pdf/cr/v29n3/a23v29n3. pdf>. Accessed: Nov. 10, 2014

LEITE, L.C. et. al. Anatomopathologic lesions found in Dioctophyma renale (Goeze, 1782) infections in domestic dogs (Canis familiaris, LINNAEUS, 1758). Archives of

Ciência Rural, v.46, n.5, mai, 2016. 
Veterinary Science, Curitiba, Brasil, v.10, n.1, p.95-101 2005. Available from: <ojs.c3sl.ufpr.br/ojs/index.php/veterinary/article/ download/4091/3318>. Accessed: Nov. 10, 2014.

LEMOS, L.S. et. al. Extra-renal lesion caused by Dioctophyma renale eggs in an erratic cycle in a dog. International Journal of Morphology, Temuco, Chile, v.28, n.4, p.1031-1034, 2010. Available from: $<$ http://www.scielo.cl/scielo.php?script=sci_artte xt\&pid=S0717-95022010000400008> . Accessed: Nov. 10, 2014 doi: $10.4067 / \mathrm{S} 0717-95022010000400008$.

LORENZ, M. Handbook of veterinary neurology. 5.ed. St. Louis: Elsevier Saunders, 2011. 560pp.

MONTEIRO, S.G. et. al. Infecção natural por trinta e quatro helmintos da espécie Dioctophyma renale (Goeze, 1782) em um cão. Revista da FZVA, Uruguaiana, v.9, n.1, p.95-99, 2002. Available from: <http://revistaseletronicas.pucrs.br/ojs/index.php/ fzva/article/viewFile/2149/1658>. Accessed: Nov. 10, 2014.

PEDRASSANI, D. Aspectos morfológicos, imunológicos e epidemiológicos do Dioctophyme renale em cães no distrito de São Cristóvão, Três Barras, Santa Catarina. 2009. 118f. Tese (Doutorado em Medicina Veterinária Preventiva) Faculdade de Ciências Agrárias e Veterinárias, UNESP, Campus de Jaboticabal, SP. Available from: <http://javali.fcav.unesp. br/sgcd/Home/download/pgtrabs/mvp/d/3249.pdf>. Accessed: Aug. 27, 2015.

PLATT, S.; OLBY, N. Manual of canine and feline neurology. 2.ed. Athens: BSVA - Bristish Small Animal Veterinary Association, 2004. 542pp.

SHARP, N.; WHEELER, S. Small animal spinal disorders diagnosis and surgery. 2.ed. Hertfordshire: Elsevier Mosby, 2005. 224pp.

ROSA, J.S.G. et al. Ocorrência de Dioctophyma renale livres na cavidade abdominal de fêmea da espécie canina submetida à cirurgia cesariana. In: SECOMV - SEMANA DE EDUCAÇÃO CONTINUADA EM MEDICINA VETERINÁRIA, 10., 2011, Espírito Santo. Anais... Vitória: UFES, 2011. Available from: $<$ http://www.secomv.com.br/trabalhos/2011/TRABALHOSPARA-ANAIS/30.pdf $>$. Accessed: Nov. 10, 2014. 